\title{
Learners' knowledge and and perceptions of voluntary Counselling and Testing for HIV and AIDS in the Free State Province
}

\author{
Y Botma \\ School of Nursing, University of the Free State
}

ZD Motiki

School of Nursing, University of the Free State

MC Viljoen

School of Nursing, University of the Free State

Correspondence address:

M. C. Viljoen

School of Nursing

University of the Free State

PO Box 339

Bloemfontein 9301

South Africa

\section{Abstract: Curationis 30(2): 48-57}

The study investigated the perceptions of the youth regarding Voluntary Counselling and Testing (VCT) and sexual aspects related to HIV and AIDS. The study was grounded in qualitative methodology, using 4 focus group interviews for data collection triangulating the results with field notes and literature. The participants of the four focus groups proved to be well informed on the topic and had clear perceptions concerning several aspects. They were very positive regarding the advantages of VCT for the prevention and management of HIV and AIDS. The participants recognised the need for the youth to be better informed about VCT and HIV and AIDS. They were much concerned by the lack of parental involvement in sexual education as well as the permissiveness of the youth who partook in alcohol and drug abuse as well as prostitution. Participants of the study stated that this problem was exacerbated by poverty and poor socio economic conditions.

\section{Opsomming}

Die doel van die studie was om die persepsies van die jeug betreffende Vrywillige Berading en Toetsing (VBT) vir MIV en VIGS asook verwante seksuale aspekte te ondersoek. Die navorsing was kwalitatief van aard. Met gebruik van 4 fokusgroep onderhoude is data versamel wat getrianguleer is met veldnotas en literatuur. Die deelnemers aan die fokusgroep besprekings, was goed ingelig oor die onderwerp en het sterk opinies gehad rakende verskeie aspekte. Hulle was baie positief oor die rol van VBT in die voorkoming en hantering van MIV en VIGS. Die deelnemers het die belangrikheid daarvan beklemtoon dat die jeug beter ingelig moet wees oor VBT en MIV en VIGS. Hulle was baie bekommerd oor die gebrek aan ouerlike bertokkenheid by seksuele opvoeding asook die permissiwiteit van die jeug wat dwelms en alkohol misbruik en betrokke is by prostitusie. Die deelnemers aan die projek het gevoel dat hierdie probleme vererger word deur armoede en algemene swak sosio-ekonomiese toestande. 


\section{Introduction}

During the last two decades, the Human Immunodeficiency Virus (HIV) and the disease caused by it known as Acquired Immune Deficiency Syndrome (AIDS) has entered our awareness as an incomprehensible calamity. HIV and AIDS has taken a terrible human toll, claiming millions of lives, leaving thousands of orphans, inflicting pain and grief, causing fear, uncertainty and threatening economic devastation in South Africa (Stadler, Morrison \& McGregor, 2000: 4).

According to Van Dyk (2002:19) the problems caused by HIV and AIDS can be systemised into two broad categories, namely prevention and management. Firstly the health sector and scientific community has to find ways of preventing the spread of the virus. And secondly, it has to solve the problems that are posed by managing the people who are already infected and who are ill or dying because of it.

Prevention of HIV and AIDS is a priority for all health sectors in South Africa. According to the National Department of Health Strategic Plan for South Africa 2002-2005 priority area number one is vested in the prevention of HIV and AIDS, especially amongst the youth (National Department of Health, 2000:15). Accordingly, numerous efforts are currently underway to reduce the rate of sexually transmitted infections including HIV in South Africa. These efforts include education programmes for encouraging safer sexual lifestyles, the supplying of condoms by the public sector and the giving of anti-retroviral (ARV) drugs where necessary. However, judging by the increased rate of HIVinfections these efforts fall short of achieving their aim of curbing the pandemic and saving lives. Seemingly these efforts have in a way successfully increased knowledge and awareness about HIV and AIDS among the population in general with little or no change in behaviour (Letsie, 2000:2).

Much research is being done worldwide to determine which intervention programmes are successful in changing sexual lifestyles among the youth. This fact was illustrated when in 2001 The Cochrane Library analysed as many as 60 research articles concerning different intervention programmes for changing sexual lifestyles (Shepard, Weston,
Peersman \& Napuli, 2001).

A very important strategy in the prevention of HIV is the process of Voluntary Counselling and Testing (VCT) whereby an individual is tested for HIV in a confidential setting. During the process of VCT the individual firstly receives counselling to prepare him/her for a positive result. A person is tested and is counselled again when the result of the test is given to him/her. In the case of a negative result the counseller will confirm his knowledge for remaining safe from HIV infection. In the case of a positive diagnosis the individual is offered ongoing emotional support, is referred for further medical evaluation and ARV treatment and is counselled on how to live a healthy lifestyle so as to protect his immune system. The person is encouraged to take all precautions not to spread the virus to others by practicing sexual risk reduction and by making his/her status known to sex partners and medical personnel where necessary.

The process of VCT is important in curbing the spread of HIV and AIDS. The reasoning is that if an individual tests negative, he will take precautions not to get infected through sexual activities by adopting safe sex practices. Conversely, if an individual tests positive, he will adopt safe sex practices, insuring that he does not infect other people, thereby stopping the spread of the virus.

The management of the health of people who are infected with HIV is the second problem that the health community faces. VCT may address this problem in the following manner: Individuals who test positive for HIV receive medical and emotional assistance and can be counselled to cope with the diagnosis. They are informed about adopting a healthy lifestyle, thus protecting the immune system as much as possible and delaying the progression of the disease. The client with a positive diagnosis as well as his family members may therefore receive timely emotional support and education about the disease. "Early detection ties in with a prolonged life and improved quality of life for those living with HIV/AIDS" (Soloman, Van Rooyen, Griesel, Grey, Stein \& Nott, 2004: 48). Medical assistance includes ARV therapy for those whose infection has progressed to a certain level of severity. ARV therapy has been offered by the public sector in South Africa since 2004. However when this study was completed, in 2003 , the public sector did not provide anti-retroviral drug therapy.

Findings from a study by LoveLife (2001:27) in Kenya found that communities placed a higher value on VCT than they did on a hypothetical AIDS vaccine, chronic care services or ARV therapy. Programmes that include VCT have been successful in countries such as Uganda and Kenya.

However, as much as researchers may value VCT, there exist almost insurmountable difficulties in the acceptance of VCT by communities. People desist from going for VCT because of the fear of stigmatisation, rejection and ostracism by the community, family, friends and loved ones once a positive diagnosis has been made. Evian (2003:22) as well as Grant, Strode and Smart (2002:134) stated that stigmatisation of HIV and AIDS often causes social rejection, and alienation and can compromise employment, housing, schooling and childcare responsibilities. "A large number of studies carried out over the last 5-10 years suggest varying degrees of negativity in the perception of people with HIV and AIDS"'(Hodgson, 1997: 283).

Overcoming the stigma associated with $\mathrm{HIV}$ is the biggest challenge to its prevention and care. Countries where VCT is well established, such as Uganda, have less stigmatising attitudes to HIV and AIDS (UNAIDS, 2001:46).

Another great barrier to VCT is the fear of a positive diagnosis. Reactions of clients to a positive diagnosis include a variety of emotions such as shock, denial, disbelief, despair, numbness and helplessness. Other emotional reactions are guilt, anxiety and depression as well as obsessional thoughts, which include frequently thinking about suicide (Evian, 2003:42). Suicidal tendencies are common with people who are tested HIV positive because the emotions that are linked with a positive diagnosis are hopelessness and negative expectations of the future (Van Dyk, 2002:278).

It is important to note at this point that many of the problems of stigmatisation and fear are based in ignorance about the transmission, diagnosis, prevention, associated symptoms and diseases as 
well as management of HIV and AIDS. Stadler et al., (2000:4) reiterated this when they named the barriers to achieving HIV prevention as being fear, denial and ignorance. Adding to this they said that the prevention of the infection of HIV has been plagued by silence resulting from the stigma associated with the disease.

It was against this background that the research topic and design was conceptualised.

It was necessary to determine the existing perceptions about VCT. In choosing an age group it was decided to concentrate on the youth because they are so much at risk of contracting HIV and AIDS (LoveLife, 2001:2). VCT is a relatively new phenomenon and until 2003 when this study was conducted, no studies concerning it had been done in the Free State.

It was decided to do a qualitative research study on secondary school learners in the Mangaung Municipality, Motheo District in the Free State to determine their perceptions of VCT. The purpose of the study was to explore and describe the perceptions of the youth on VCT. The information gained could be an important guide to policy formation concerning VCT at regional and national levels in South Africa.

As is the case with most qualitative research, the results of the study yielded more information concerning issues related to HIV and AIDS than only the youth's perceptions of VCT.

\section{Method}

A descriptive design using qualitative methods of data collection was used. Focus group interviews were conducted with secondary school learners to explore and describe the phenomenon of youth perception of VCT. These focus group interviews were triangulated with field notes and literature thereby enhancing the trustworthiness, richness and rigor of the data collected.

\section{Population and sampling method}

One of the secondary schools in the Mangaung Municipality Motheo District was purposefully selected, on the basis of language, to form the population of the study. The learners of this school speak IsiXhosa, which is the mother tongue of the researcher as well as the moderator. The Free State Department of Education was contacted to find a school whose baseline language was IsiXhosa. Therefore the target population consisted of all the learners in one secondary school of the Mangaung Municipality Motheo District comprising 929 learners from Grades eight to twelve.

In an effort to reduce the influence of "pecking order" of junior and senior learners on the groups being studied, the two extreme ends were excluded from the study. These were the learners in grades eight and twelve. This strategy made the age distribution smaller and the groups more homogeneous, which adds to the trustworthiness of the study.

\section{Selection and size of focus groups}

According to Polit, Beck \& Hungler (2001:325) a guiding principle in sampling is the data saturation principle, which means sampling to the point at which no new information is obtained and redundancy is achieved. Morse (1998:76) states that: "In qualitative research, adequacy refers to the amount of data collected, rather than the number of subjects, as in quantitative research". Adequacy is thus attained when sufficient data have been collected in order that saturation may occur and variation is both accounted for and understood.

Accordingly the principle of data saturation for focus groups interviewed, was applied and because saturation had occurred after the fourth group, no further interviews were nceded.

Babbie (2001:294) suggests that focus groups should consist of 12 to 15 people. Therefore the researcher selected four groups of 15 learners that would form the focus groups. With this number of learners in a group, provision could be made for absenteeism or non-attendance. The percentage of learners in each grade and gender group was calculated so that each focus group would consist of a representatively correct proportion of grade and gender. Selection from these proportions was done according to the dpurposive sampling method in that the learners were chosen which had certain pre-identified characteristics. The Life Skills teacher was used as the "gatekeeper" because she knew the children well enough to assist with the selection criteria. These criteria and the reasons for implementing them, are explained below. Learners were selected that were:

- Older than 14 years:

Children at this age are interested and knowledgeable about sexual matters since they are adolescents (Coleman, 2001:14)

- $\quad$ Selected from grades nine to eleven:

This was done to reduce the "pecking order" of junior and senior learners on the other learners

Able to communicate in English
and IsiXhosa:
The researcher wanted
participants who could speak
Xhosa but who had been
educated in English and
therefore comfortable with all
terminology regarding HIV and
AIDS.

- $\quad$ Outspoken and able to take active part in the discussion: This was to ensure a variety of participants' perceptions.

\section{Data collection}

The study was conducted using the qualitative method of focus group discussions, observation and documentation and results of each method were triangulated with that of the other as well as with literature. The following steps were implemented in the procedure:

\section{Ethical considerations and consent}

Permission to conduct the study was obtained from all relevant parties beforehand. These included amongst others the participants, their parents, teachers and school principal. Everyone involved was briefed on exactly how and where the study would take place so that they could give informed consent. Confidentiality was ensured and kept throughout the study and raw data were secured and burnt after completion of the study. All participants took part in the study voluntarily and they were informed that they might discontinue their participation at any point of the proceedings.

\section{Focus groups}

Focus groups provides the interviewer 
with the opportunity of observing the population being studied first hand and gaining an in depth meaning-, and thus valid insight and understanding of the phenomenon being studied (Babbie, 2001:294; Greeff, 2002:313).

Gibbs (1997: http://www.soc.surrey.ac. $\mathrm{uk} / \mathrm{sru} / \mathrm{SRU}$ 19html) stated that the main purpose of focus group research is to draw upon participants' attitudes, feelings, beliefs experiences and reactions concerning the topic being discussed.

The actual research for this study was done at a secondary school, chosen for its baseline language of Isixhosa. Before each focus group discussion took place, care was taken to create a relaxed atmosphere among the participants and to provide them with the opportunity to build rapport with the moderator, researcher and study leader. According to Neuman (1997:355) a field researcher needs social skills and personal charm to build rapport. Prior to interviews in focus groups, participants met informally for thirty minutes with the moderator, the researcher and the study leader. Snacks and coffee were provided. Purposeful small talk avoids discussion of the research topic and instead concentrates on common human experiences such as the weather or sports (Krueger \& Casey, 2000:103).

The focus group discussions were conducted at the school in a quiet setting with learners placed in a circle to promote good communication among them. The moderator was part of the circle while the researcher and study leader were seated outside the circle so as not to be part of the group. They acted as participant observers. The tape recorder was placed in the middle of the group in full view. It was tried to create a relaxed, natural and non-threatening atmosphere by building rapport and by using a skilled moderator.

The moderator was a qualified psychiatric nurse with experience in conducting focus group discussions. She was fluent in English and IsiXhosa, which are the two languages, used in the region and in which participants could express themselves. The moderator posed the following open-ended question to the group:

"What is your perception of Voluntary Counselling and Testing for HIV and AIDS?"
The data collection was done as meticulously as possible.

The moderator requested that everyone should not speak at once but encouraged spontaneity. It was stressed that the tape recordings could not be linked to any names. To ensure this the participants were given numbers by which they would be known.

The spontaneity and openness of the learner's discussions indicated that good rapport had been established with the moderator. Although some participants were not actively involved by speaking all the time they leant forward which in body language indicated their interest in the ongoing discussions.

\section{Field notes}

While the focus group discussions were in progress, the researcher took descriptive, observational, theoretical and personal notes. These notes described the unstructured observations made during the discussions as well as the interpretation of these observations. The observations included seating arrangements of participants, the order in which people spoke to aid voice recognition, non-verbal behaviour of participants, themes that were striking as well as personal thoughts, ideas, hunches and impressions.'

The importance of field notes is that they aid the researcher in focussing on group dynamics which is important in the analyses of data since the strength of focus groups lie in the process of sharing and comparing among the participants (Polit \& Hungler, 1999:369).

\section{Trustworthiness}

Trustworthiness is described by Polit and Hungler (1999:430) as credibility, dependability and confirmability. The credibility of the study was high due to the skill and professionalism of the study leader and supervisor of the project as well as triangulation of the focus group interview data, field notes and literature. Credibility is also described by Polit and Hungler (1999:430) as "truth value", and therefore the prolonged engagement of the researcher with the participants during the focus group interviews as well as the fact that she was of the same language and cultural group as the participants, is regarded as adding to the trustworthiness of the study. Dependability of the analyses of the data was increased by using a co-coder.
Confirmability was added to because the researcher directly observed and interacted with the participants in their natural setting during the data collecting phase.

\section{Data analyses}

A qualitative data analysis is a time consuming and intensive activity clustering together the related narrative information into a coherent structure. The researcher has to familiarise herself with the data by rereading of transcripts. Working together with a co-coder, points of interest are underlined, meaning is attached to elements in the data and notes are made along the margin. Data were analysed from field notes as well and were coded and categorized. Coding refers to the process of transforming raw data into standardised form and entails the identifying of recurring words, themes and concepts within the data (Polit et al, 2001:697).

The data were grouped according to themes and categorised and subcategorised. The main categories were formed by the categories of the KAPB model namely, Knowledge, Attitudes, Practices and Beliefs. (See table 1). This model was derived from the Health Belief Model and was developed to help determine whether an individual is likely to participate in disease prevention and health promotion activities (Kozier, Erb, Bergman \& Snyder, 2004: 178). According to Morna and Lush (2003: http://www.genderlinks.org.za/docs/ 2003/hiv-training-manual/liv-ch4.pdf) the $\mathrm{KAPB}$ model can lead to a gain in knowledge, a change in beliefs and attitudes and eventually a change in practices and behaviours.

\section{Presentation of the findings}

The findings indicated that the learners who participated in this study had well defined perceptions regarding VCT. As this was a qualitative study, findings of perceptions regarding related issues of HIV and AIDS were disclosed and were reported according to the KAPB model.

\section{Knowledge}

All four focus group participants knew about HIV and AIDS and that it had a high mortality rate amongst the youth. They were knowledgeable about the role of VCT in prevention of HIV and AIDS 
Table 1: Frequencies of responses from four focus group interviews

\begin{tabular}{|c|c|c|c|c|c|c|}
\hline \multirow[t]{2}{*}{ Main category } & \multirow[t]{2}{*}{ Sub-category } & \multirow[t]{2}{*}{ Themes } & \multicolumn{4}{|c|}{ Four Focus group interviews } \\
\hline & & & 1. & 2. & 3. & 4. \\
\hline \multirow[t]{4}{*}{ Knowledge } & VCT \& prevention & $\begin{array}{l}\text { Must test } \\
\text { Know your status }\end{array}$ & $\begin{array}{l}\mathrm{x} \\
\mathrm{x}\end{array}$ & $\begin{array}{l}\mathrm{x} \\
\mathrm{x}\end{array}$ & $\begin{array}{l}\mathrm{x} \\
-\end{array}$ & $\begin{array}{l}x \\
-\end{array}$ \\
\hline & Barriers against VCT & $\begin{array}{l}\text { Fear } \\
\text { Rejection } \\
\text { Suicide }\end{array}$ & $\begin{array}{l}x \\
x \\
x\end{array}$ & $\begin{array}{l}\mathrm{x} \\
\mathrm{x} \\
\mathrm{x}\end{array}$ & $\begin{array}{l}- \\
x \\
x\end{array}$ & $\begin{array}{l}- \\
\mathrm{x} \\
\mathrm{x}\end{array}$ \\
\hline & Modes of transmission & Infected blood & $x$ & $\mathrm{x}$ & $\mathrm{x}$ & $\mathrm{x}$ \\
\hline & Sources of information & $\begin{array}{l}\text { Media } \\
\text { Youth groups at school }\end{array}$ & $\begin{array}{l}x \\
x\end{array}$ & $\begin{array}{l}\mathrm{x} \\
\mathrm{x}\end{array}$ & $\begin{array}{l}\mathrm{x} \\
\mathrm{x}\end{array}$ & $\begin{array}{l}\mathrm{x} \\
\mathrm{x}\end{array}$ \\
\hline \multirow[t]{5}{*}{ Attitudes } & Media & Explicit sex scenes & $x$ & - & - & - \\
\hline & Parental guidance & $\begin{array}{l}\text { No guidance } \\
\text { Parents are ignorant }\end{array}$ & $\bar{x}$ & $\begin{array}{l}\mathrm{x} \\
\mathrm{x}\end{array}$ & - & $\begin{array}{l}\mathrm{x} \\
\mathrm{x}\end{array}$ \\
\hline & School guidance & Sex education in the curriculum & $x$ & $\mathrm{x}$ & $\mathrm{x}$ & $\mathrm{x}$ \\
\hline & Disclosure & $\begin{array}{l}\text { To sex partner } \\
\text { By doctors to families } \\
\text { By traditional healers to families }\end{array}$ & $\begin{array}{l}\mathrm{x} \\
\mathrm{x} \\
\mathrm{x}\end{array}$ & $\begin{array}{l}x \\
x \\
x\end{array}$ & $\begin{array}{l}\mathrm{x} \\
\mathrm{x} \\
\mathrm{x}\end{array}$ & $\begin{array}{l}\mathrm{x} \\
\mathrm{x} \\
\mathrm{x}\end{array}$ \\
\hline & Development of self concept & $\begin{array}{l}\text { Empowerment to say no to sex } \\
\text { Empowerment to use condoms }\end{array}$ & $\begin{array}{l}x \\
x\end{array}$ & $\begin{array}{l}\mathrm{x} \\
\mathrm{x}\end{array}$ & $\begin{array}{l}\mathrm{x} \\
\mathrm{x}\end{array}$ & $\begin{array}{l}\mathrm{x} \\
\mathrm{x}\end{array}$ \\
\hline \multirow[t]{3}{*}{ Practices } & Peer counselling & $\begin{array}{l}\text { Easier to speak to a peer } \\
\text { Youth programs run be youth }\end{array}$ & $\begin{array}{l}x \\
x\end{array}$ & $\begin{array}{l}\mathrm{x} \\
\mathrm{x}\end{array}$ & $\begin{array}{l}\mathrm{x} \\
\mathrm{x}\end{array}$ & $\begin{array}{l}\mathrm{x} \\
\mathrm{x}\end{array}$ \\
\hline & Pre and post-test counselling & $\begin{array}{l}\text { Ethical and legal right } \\
\text { Support is made possible } \\
\text { Keeping safe is encouraged }\end{array}$ & $\begin{array}{l}x \\
x \\
x\end{array}$ & $\begin{array}{l}\mathrm{x} \\
\mathrm{x} \\
\mathrm{x}\end{array}$ & $\begin{array}{l}\mathrm{x} \\
\mathrm{x} \\
\mathrm{x}\end{array}$ & $\begin{array}{l}x \\
x \\
x\end{array}$ \\
\hline & Sexual risk reduction & $\begin{array}{l}\text { Abstinence } \\
\text { Condoms } \\
\text { Masturbation } \\
\text { Thigh sex } \\
\text { Virginity testing }\end{array}$ & $\begin{array}{l}\mathrm{x} \\
\mathrm{x} \\
\mathrm{x} \\
\mathrm{x} \\
\mathrm{x}\end{array}$ & $\begin{array}{l}x \\
x \\
x \\
- \\
-\end{array}$ & $\begin{array}{l}x \\
x \\
x \\
- \\
-\end{array}$ & $\begin{array}{l}\mathbf{x} \\
\mathbf{x} \\
- \\
- \\
-\end{array}$ \\
\hline \multirow[t]{4}{*}{ Beliefs } & Value clarification & $\begin{array}{l}\text { Partner loyalty } \\
\text { Abstinence } \\
\text { Alcohol, drugs and morality } \\
\text { Poverty and prostitution }\end{array}$ & $\begin{array}{l}x \\
x \\
x \\
x\end{array}$ & $\begin{array}{l}x \\
x \\
x \\
x\end{array}$ & $\begin{array}{l}\mathrm{x} \\
\mathrm{x} \\
\mathrm{x} \\
\mathrm{x}\end{array}$ & $\begin{array}{l}\mathrm{x} \\
\mathrm{x} \\
\mathrm{x} \\
\mathrm{x}\end{array}$ \\
\hline & Support for PLA & $\begin{array}{l}\text { Encourage VCT } \\
\text { Support groups for PLA }\end{array}$ & $\begin{array}{l}\mathrm{x} \\
\mathrm{x}\end{array}$ & $\begin{array}{l}\mathrm{x} \\
\mathrm{x}\end{array}$ & $\begin{array}{l}\mathrm{x} \\
\mathrm{x}\end{array}$ & $\begin{array}{l}\mathrm{x} \\
\mathrm{x}\end{array}$ \\
\hline & Religion and culture & $\begin{array}{l}\text { Morals and religion } \\
\text { African culture and sexual } \\
\text { guidance }\end{array}$ & $\begin{array}{l}x \\
x\end{array}$ & $\begin{array}{l}\mathrm{x} \\
\mathrm{x}\end{array}$ & $\begin{array}{l}\mathrm{x} \\
\mathrm{x}\end{array}$ & $\begin{array}{l}\mathrm{x} \\
\mathrm{x}\end{array}$ \\
\hline & Misconceptions and Myths & $\begin{array}{l}\text { Paying for VCT } \\
\text { Condoms have holes } \\
\text { Virgin Cleansing }\end{array}$ & $\begin{array}{l}\mathrm{x} \\
-\end{array}$ & - & - & - \\
\hline
\end{tabular}


as well as the barriers against VCT. They knew about other modes of transmission apart from the sexual, and where to obtain information regarding the disease.

Voluntary counselling and testing and prevention of HIV and AIDS

All participants knew about the importance of VCT. The following quotations bear testimony to their convictions and are presented verbatim:

"People must go for the test. AIDS must be prevented in anyway. Prevention is better than cure."

"You are not negative until you have tested; the only way to stop the spread is you must test."

\section{"You must know where you stand."}

Studies demonstrating that sexual risk behaviours are reduced significantly with VCT come from a number of developing countries (UNAIDS, 2001:46). The recent multi-centre VCT efficacy trial was the first randomised trial of VCT from developing countries. It demonstrated that VCT resulted in greater behaviour change than health education alone. The study also indicated that sero-positive people were more likely than seronegative people to show significant behaviour changes in developed countries as opposed to developing countries where this behavioural change was less significant (UNAIDS, 2001:46).

\section{Barriers against VCT}

The focus groups confirmed the existence of barriers against VCT. All four focus groups agreed that people do not go for VCT because of the fear of being tested positive and then being stigmatised by others. Added to this, there was the fear of dying and thoughts of suicide. Stadler, Morrison and Mc Gregor (2000:4) states that HIV and AIDS are largely associated with stress, prolonged suffering and death and Van Dyk (2002:278) maintains that HIV and AIDS are associated with an increased likelihood of suicide. These were some of the comments;

"Some parents have a negative attitude they will say she or he is no longer my daughter or son if a person is HIV positive."

"Other people say if I am HIV positive, I am going to kill myself."

\section{Modes of transmission}

Participants were well informed about the mode of spreading of the disease other than through sexual contact. In view of the fact that HIV can be contracted via other means than sexual contact, the four focus groups stated the importance of VCT even for people who are not sexually active, as indicated by the following verbatim statement:

"When you touch the blood of HIV positive person you can get AIDS if you have a sore."

\section{Sources if Information}

Sources of sexual information were mainly the media and youth group activities presented by schools. The media in the form of TV, radio, newspapers, posters, pamphlets as well as books and movies, is a rich source of information on HIV and AIDS (Neethling and Schocman, 1999:72).

The four groups recommended a variety of novel ways of teaching about HIV and AIDS. Dramas, debating teams, RAP music and even youth groups going from house to house were some of the suggestions made by the participants.

Some participants raised the valid point that there is enough information from the media but that it is just ignored by many young people, as revealed by the following statement:

"People do not listen; I think the government should stop advising people about AIDS because it is a waste of money we are like monkeys."

\section{Attitudes}

The participants of the four focus groups had clearly expressed attitudes regarding the role of the media in promoting promiscuity, the inadequacy of school and parental guidance in curbing the disease and the role of doctors and traditional healers in non-disclosure of patients' HIV status. They also felt that the development of a strong self-concept would empower the youth against highrisk sexual behaviour.

\section{The media}

Several participants were outspoken against the incidence of sex in the movies:

"I think the media must replace sex in the movies with an educational program."
Two participants were outspoken about the visual sexual stimulation caused by movies showing explicit sex and according to Louw, Weitz and Radebe (1996:71) mass media confuse the children about moral and ethical issues surrounding sexual behaviours.

The need for more information by the media was expressed as well. Literature from the following sources supports this fact (Maker, 2002:25; Alan Guttmacher Institute, 2003: http:/www.org/press/ 2001/07/turkey0724-ltr.htm)

\section{Parental guidance}

All participants agreed that they were not getting enough parental guidance regarding HIV and AIDS. Literature supported this view (Davey, $1991 \mathrm{http}: / /$ www.population.org.za/reach). According to The Alan Guttmacher Institute (2003: http:/www.org/press/ 2001/07/turkey0724-Itr.htm) parents are concerned about HIV and AIDS but do not seem to be convinced that open communication about sex and sexuality can reduce the risk of HIV infection.

\section{"Our parents do not talk to us about sex."}

"Parents must be taught how to talk to us about sex."

\section{School guidance}

All four groups felt that more sexual education and information on HIV and AIDS must be given at school and that it should form part of the Life Skills Education program. This opinion is supported by Van Dyk (2002:155) who agrees that HIV and AIDS education should be integrated into the existing school curriculum.

Two of the groups said that they had received information from the government via health workers who visited the schools to give sex education. They indicated that the clinics provided information as well.

\section{Disclosure}

The focus groups were greatly concerned about the problem posed by keeping HIV status confidential since they felt that the spread of HIV and AIDS would continue while people are protected by law from disclosing their status.

The four focus groups felt that people should disclose their status to their sexual 
partners.

They were of the opinion that when a person has died of AIDS and the doctors and families and traditional healers obscures this fact by saying that the cause of death was some other illness; they are exacerbating the problem of HIV and AIDS.

"Doctors nill not say a person died of AIDS. They will say the person died of TB or cancer. "

"Witchdoctors or fortune tellers must not lie, they must tell the truth about the illness (AIDS) of the person, because they tell the people that they are bewitched and yet they are dying of AIDS."

\section{Development of self-concept}

The idea that a strong self-concept would lead to empowerment of oneself was expressed and discussed by the groups. Kutz (1997:26) stated that empowerment occurs when one becomes able to take action for oneself. It is accompanied by a growing belief in oneself and the growth of self-confidence.

All four focus groups were in agreement with the principle of living a positive life and avoiding high-risk sexual behaviours. This included the willingness to go for VCT. They emphasized the need for the youth to change their sexual behaviour, not being influenced by peer pressure, not being coerced into a sexual relationship by a partner and saying "no" to sex with pride. They advocated the development of selfrespect and assertiveness.

\section{"Be able to say' no to sex. Say' it with pride."}

"Being cool is not drinking and smoking and having sex, it is about doing what is right."

There was concern for the empowerment of women in unequal relationships such as those married to - and living with HIV positive men. There was also concern for learners in disempowered relationships. The development of a strong self-concept as related to assertiveness for women in unequal relationships was advocated.

\section{Practices}

The participants had certain perceptions regarding peer counselling, pre-and post- test counselling and practices regarding sexual risk reduction.

\section{Counselling}

Participants from all four focus groups strongly supported peer counselling. Suggestions were made that young people should work at clinics because it is easier to speak to a peer than to an adult about sensitive issues.

Peer counselling is supported by literature, which states that behaviour change is most likely to occur when peers educate, empower and support each other. That means that youth programs should be run by young people. A successful peer education program transfers the control of knowledge from the hands of experts to the lay members of the community, thereby making the educational process more accessible and less intimidating (Cox, 1999:4; Stanhope \& Lancaster, 1988:78).

\section{Pre and post-test counselling}

All participants agreed that counselling should be done before and after an HIV test. The client should be prepared fully to face the outcome of the results. They knew that voluntary confidential pre- and post-test counselling is the ethical and legal right of each person. It is of invaluable importance to prepare the person for the outcome of the test. After a positive finding it is functional in supporting the sero-positive person both emotionally and physically and encouraging him/her to preventing the spread of the disease. The post-test counselling of a person who has tested negative functions to influence the person to stay negative by implementing safer sex practices.

\section{Sexual risk reduction}

Reducing the rate of HIV infection among teenagers would lead to a substantial slowing of the epidemic over the next five to ten years. Conversely, failure to curtail the rate of infection in this age group could sustain an epidemic of catastrophic proportions for future decades (Stadler, et al., 2000:1). The focus groups had strong convictions regarding the need to stop the spread of HIV and AIDS through the advocacy of abstinence and/ or safer sexual practices.

\section{Abstinence}

All groups were of the opinion that abstinence was the most practical way of protecting oneself from HIV-infection.
"I think we nust abstain from sex before marriage"

"Sex is not for children, it is not a game"

\section{Safersex}

The four focus groups were aware of high risk sexual practices and agreed that sex without a condom is a number one high risk factor for contracting HIV and AIDS.

The perceptions and opinions of the participants regarding safer sex were the following:

- $\quad$ The use of condoms. The majority of the four groups were in favour of using male and/or female condoms for preventing transmission of HIV and AIDS

- Masturbation. There were mixed reactions to the practice of masturbation. Two groups were in favour of masturbation as a form of preventing the spread of HIV and AIDS. Some participants were however opposed to it without giving valid reasons. Van Schaik (2002:243) says that attitudes towards masturbation are usually based on cultural and religious beliefs.

- $\quad$ Thigh sex. Only one group mentioned thigh sex as an option for curbing the spread of HIV and AIDS.

- Virginity testing. Only one male participant encouraged this method of practicing safer sex but the other participants did not entertain the idea. Research as done by Leclerc-Madlala (2003:7) says that virginity testing may lead to harassment or banishment of girls by communities.

\section{Beliefs}

The participants of all four groups stated their beliefs in upholding moral values as advocated by different religions and cultures and supporting people living with HIV and AIDS.

Some misconceptions and myths were voiced.

\section{Values clarification}

The focus groups were strongly in favour of virtues such as loyalty and trust among partners as well as abstinence from sex until marriage, and were opposed to married men who are unfaithful to their 
spouses. However according to the Population Registration Bureau (2004: http://www.populatioin.org.za) there is a high level of sexual activity among learners. Nationally, two thirds of thirteen year-olds in South Africa are estimated to have already experienced their first sexual encounters.

The four focus groups agreed that alcohol and drug abuse has a great impact on the youth, exposing them to high-risk sexual behaviours.

Three groups stated that prostitution was a prominent factor in the spread of HIV and AIDS. With regard to prostitution they alleged that poverty was an instigating factor. Evian (2003:13) confirms this opinion in saying that poverty, unemployment and poor socioeconomic conditions are the factors that exacerbate prostitution and thus the spread of HIV and AIDS.

\section{Support}

Participants agreed that support for people living with HIV and AIDS (PLA) would lower the prevalence rate of the disease. The reasoning behind this belief is that people would go for VCT and disclose their status if they did not fear stigmatisation and knew that they could count on the support of the community. The focus groups were much in favour of setting up support groups for people living with HIV and AIDS.

"Being HIV positive is no longer a death sentence."

"We need to help others to prevent the spread of HIV."

\section{Religion and culture}

The four focus groups voiced strong opinions about the need for the youth to change their moral behaviour to be in line with the teachings of their different religions.

Participants had concerns that in traditional African culture parents do not discuss sexuality issues with their children, thus preventing their guidance concerning sexual practices, HIV and AIDS.

\section{Misconceptions and myths}

There were a few participants who wrongly thought that one had to pay for VCT and did not know that it was available free of charge in South Africa.
A few participants who had negative comments about the use of condoms saying that condoms have holes in or can burst. Summerton (2001:60) alleges that people do not like using condoms and prefer having sex "flesh to flesh".

Only one boy mentioned that he knew of "other people" who believe the virgin cleansing myth.

\section{Discussion of field notes}

The researcher described the transactions and processes observed during the data collection phase. She observed and documented seating arrangements, conversations, non-verbal language and rapport between participants as well between participants and moderator, researcher and study leader. Personal notes and comments concerning her feelings during the interviews were documented as well.

The researcher observed that participants were open and free in their discussions of VCT. No one felt intimidated in the group. Rapport with the moderator was good and there was mutual trust. Some of the participants were not verbally active in discussions but were leaning forward, thereby showing interest.

\section{Discussion}

VCT is a very sensitive topic to discuss especially with young people because it has a might have a connotation of encouraging sexual activity. Taking into consideration that it is not accepted in African culture to talk about sex with young people, the youth that were interviewed were open-minded in discussing their views on VCT, sexual practices, HIV and AIDS.

In conclusion it can be said that the four focus groups were knowledgeable about HIV and AIDS as well as VCT in particular. They were willing to participate in the discussions, had informed opinions and expressed their feelings.

All groups were in favour of VCT and had insight in to the manner in which VCT can aid the prevention and management of HIV and AIDS. They were adamant that people should be encouraged to come forward for VCT and the emphasis should be on "knowing your status".

The study revealed that young people are aware of their rights with regard to testing for HIV. It was mentioned several times that pre- and post-test counselling is imperative, empowering the individual to deal with the result in a positive and constructive manner.

Most preventative strategies have been based on the premise that increased knowledge about HIV and AIDS will lead people to adopt safer sex practices. The fact that the prevalence of the disease remains high in South Africa seems to suggest that this approach has fundamental shortcomings (Summerton, 2001:13). People are now encouraged to make use of VCT to find out their HIV status so as to curb the spread of the disease.

This study also confirmed that there is a great need for the youth to be informed about HIV and AIDS. The media was cited as the best way to inform the youth such as TV, radio, dramas and posters. Other modes that were indicated to provide HIV and AIDS information were workshops, music, group discussions, debates and going from house to house to provide HIV and AIDS information.

The study cited the lack of parental guidance as one of the major obstacles to informing the youth about safer sex practices. African culture prohibits parents from talking to their children about sex. Parents should be taught skills on how to communicate to their children about sex.

Participants of the study felt that education and life skills training in junior and secondary schools which were direct, specific and concrete would be invaluable in informing young people on ways to curb the spreading of HIV and AIDS.

The functioning of the groups was in line with the observations of the researcher and the results of the discussions are on par with literature. This study adheres to the principles of trustworthiness in qualitative research.

The limitations of the study lie in the fact that the results of the focus groups cannot be generalized to the whole population. However generalization in a qualitative study such as this is not significant because the study has intrinsic value of its own and has heuristic relevance. This value is reflected in that 
the reader is able to recognise the phenomenon described in the study, its theoretical significance, its applicability to nursing practice and its influence on future research activities.

\section{Conclusion}

The objective of the study was to determine the perceptions of the youth about VCT. During this process other perceptions of the youth concerning HIV and AIDS became apparent. They also presented their opinions as to how some problems related to the prevention and management of HIV and AIDS can be addressed. The study indicated that the learners who were interviewed knew about VCT and that it was their perception that VCT might be implemented to prevent the spread of the disease and help manage the lives of those people already influenced by it.

\section{References}

ALAN GUTTMACHER INSTITUTE

2003: Sexual and reproductive health implications. [online] http://www.org/ press $/ 2001 / 07 /$ turkey0 724 -ltr.htm [Accessed: 21 May, 2004].

BABBIE, E 2001: The practice of social research. $9^{\text {th }}$ edition. Belmont: Wadsworth/ Thomsom Learning.

BEUKES, A 2003: Referencing guidelines for post-graduate studies. (In: Lategan, L.O.K., Vermeulen, W. and Truscott, M. Eds. 2003: Research made easy. Part 1: A general overview of the research process and context. Bloemfontein. Technikon Free State: Tekskor BK.

COX, JR 1999: A guide to peer counselling. New Jersey: Jason Aronson.

DAVEY, D 1991: Let us reach everyone with accessible, friendly family planning and sexuality-education. [Online]. http:/ /www.population.org.za/reach [Accessed: 28 October, 2003].

EVIAN, C 2003: Primary HIV and AIDS care: A practical guide for primary health care personnel in the clinical and supportive care of people with HIV/AIDS. 4th edition. Houghton: Jacana.

GIBBS, A 1997: Focus groups social research update. [Online]. http:// www.soc.surrey.ac.uk/sru/SRU19html
GRANT, KB; STRODE, A \& SMART, R 2002: Managing HIV/AIDS in the workplace. A guide for government departments. Pretoria: The Department of Public Services and Administration.

GREEFF, $M$ 2002: Information collection: interviewing. In: De Vos, A. S., ed. Research at grass roots: For the human service professions. 2 nd ed. Pretoria: van Schaik.

HODGSON, I 1997: Attitude toward people with HIV/AIDS: Entropy and health care ethics. Journal of Advanced Nursing, 26: 283-288.

KOZIER, B; ERB G; BERGMAN, A \& SNYDER, SJ 2004: Fundamentals of nursing. Concepts, process, and practice. 7th edition. New Jersey: Prentice Hall.

KRUEGER, RA \& CASEY, MA 2000: Focus groups. A practical guide for applied research. Thousand Oaks: Sage.

KUTZ, LF 1997: Self-help and support groups. A handbook for practitioners. Thousand Oaks: Sage.

LECLERC-MADLALA, S 2003: The Big Test. Sunday Times / LoveLife. Scamtoprint

LETSIE, TMM 2000: Employee prevalence of HIV infection amongst Bloemfontein Municipal employees. M.Soc.Sc.Nursing Dissertation. Bloemfontein: University of the Free State.

LOUW, CD; WEITSZ, GH \& RADEBE, CV 1996: Family and sexuality education. Bloemfontein: Kagiso.

LOVELIFE, 2001: Impending catastrophe revisited. An update on the HIV/AIDS epidemic in South Africa. Talk About It. Lovelife. Johannesburg: CTP Web.

MAKER, A 2000: Raising children to their best. A guide for parents. Soul Buddyz. Johannesburg: Soul City.

MINISTRY OF EDUCATION, YOUTH AFFAIRS, 2001: Report on the National KAPB Survey on HIV/AIDS. Barbados: The division of Youth Affairs and Sports.

MORNA, CL \& LUSH, D 2003: Communicating HIV/AIDS [Online]. http:/www.genderlinks.org.za/docs/ 2003/hiv-training-manual/liv-ch4.pdf [Accessed: 22 May, 2004].

MORSE, JM 1998: Qualitative nursing research: Contemporary dialogue. New york: Sage.

NATIONAL DEPARTMENT OF HEALTH. 2000: HIV/AIDS and STD Strategic Plan for South Africa 2000-2005. Pretoria: Government Printer.

NEETHLING, $K$ \& SCHOEMAN, R 1999: Smart parents. Creating an exciting future for teenagers. Vanderbijlpark: Creda Communications.

NEUMAN, WL 1997: Social research methods: Quantitative and qualitative approaches. London: Allyn \& Bacon.

PENDER, NJ 1996: Health promotion in nursing practice. Stamford Connecticut: Appleton \& Lange.

POLIT, DF; BECK, CT \& HUNGLER, BP 2001: Essentials of nursing research Methods, appraisal, and utilization. Philadelphia: Lippincott Williams and Wilkins.

POPULATION REGISTRATION BUREAU 2004: [Online]. http:// www.populatioin.org.za [Accessed: 30 August, 2004].

SHEPARD,J; WESTON, R; EERSMAN, G \& NAPULI, 1 2001: Interventions for encouraging sexual lifestyles and behaviours intended to prevent cervical cancer. The Cochrane Library (2).

SOLOMON, V; VAN ROOYEN, H; GRIESEL, R; GRAY, D; STEIN, J \& NOTT, V 2004: Critical review and analysis of voluntary counselling and testing literature in Africa. [Online]. http; /www.hst.org.za [Accessed: 15 July, 2004].

STADLER, J; MORRISON, L \& MCGREGOR, $K$ 2000: Love them enough to talk about sex. LoveLife Publication. Johannesburg: LoveLife.

STANHOPE, M \& LANCASTER, J 1998: Community health/nursing process and practice for promoting health. St. Louis: C.V. Mosby.

SUMMERTON, JV 2001: Perception 
among a group of at risk Individuals: The discrepancy between unsafe sex practices and knowledge about HIV/ AIDS. transmission. M.Soc.Sc.Nursing Dissertation. Bloemfontein: University of the Free State.

\section{THEUNITEDNATIONSPROGRAMME} ON HIV AND AIDS (UNAIDS), 2001:

The impact of voluntary counselling and testing: A global overview of the benefit and challenges. Geneva, Switzerland: UNAIDS.

VAN DYK, A 2002: HIV/AIDS care and counselling. A multidisciplinary approach. Cape Town: Maskew Miller Longman.

VAN SCHAIK, JL 2002:. Responsible teenage Sexuality. A manual for teachers, youth leaders and health professionals. Paarl: Paarl Print. 